\title{
Profil Lemak Darah Sapi Perah Laktasi Akibat Suplementasi Baking Soda dalam Pakan
}

\author{
Blood Lipids Profile in Lactating Dairy Cows after Supplementation of Baking Soda in Feed
}

\author{
A. F. Faza, C. B. Soejono, S. M. Sayuthi dan S. A. B. Santoso \\ Fakultas Peternakan dan Pertanian Universitas Diponegoro \\ Tembalang 50275, Semarang, Indonesia \\ Koresponden e-mail: $\underline{\text { arrasfaza01@gmail.com }}$
}

\begin{abstract}
The aims of the research was to assess the effect of supplementation of sodium bicarbonate in feed rations on the blood lipids profile of lactating dairy cows including triglycerides, cholesterol, low density lipoprotein (LDL) and high density lipoprotein (HDL). This research was an experimental research using complete randomized design with 3 treatments $(\mathrm{T} 0=$ control; $\mathrm{T} 1=$ supplementation of baking soda $0,8 \% \mathrm{DM}$; $\mathrm{T} 2=$ supplementation of baking soda 1,0\% DM) and 4 replications. The materials used were12 lactating Friesian Holstein cows in the $1^{\text {st }}$ lactation period and the month of $5^{\text {th }}$ and $6^{\text {th }}$ lactations. The experiment used a completely randomized design with 3 treatments and 4 replications. The result showed that triglycerides level for T0, T1 and T2 respectively were 56,$11 ; 63,56 ; 60,14 \mathrm{mg} / \mathrm{dl}$, cholesterol levels were 250,16;224,30;221,18 mg/dl, LDL levels were 132,09; 112,69; 103,01 mg/dl; and HDL levels were 106,80; 100,50; 106,20 mg/dl. The level of triglycerides, cholesterol, LDL and HDL of blood were not significantly different between treatments $(\mathrm{P}>0.05)$. The conclusion of this research is supplementation of baking soda in feed up to $1.0 \%$ of Dry Matter does not affect metabolism in rumen.
\end{abstract}

Key words :baking soda, triglycerides, cholesterol, lipoprotein.

\begin{abstract}
ABSTRAK
Penelitian ini bertujuan untuk mengkaji pengaruh suplementasi baking soda terhadap profil lemak darah yang meliputi trigliserida, kolesterol, low density lipoprotein (LDL) dan high density lipoprotein (HDL). Penelitian ini merupakan penelitian eksperimen yang menggunakan rancangan acak lengkap (RAL) dengan 3 perlakuan (T0 = kontrol; T1 = suplementasi baking soda 0,8\% BK; dan T2 = Suplementasi baking soda 1,0\% BK) dan 4 ulangan. Materi yang digunakan dalam penelitian ini yaitu 12 ekor sapi perah Friesian Holstein (FH) laktasi pada periode laktasi 1 dan bulan laktasi ke-5 dan ke-6. Hasil penelitian menunjukkan bahwa kadar trigliserida pada T0, T1 dan T2 berturut-turut adalah 56,11; 63,56; 60,14 mg/dl, kadar kolesterol darah 250,16; 224,30; 221,18 mg/dl, kadar LDL darah 132,09; 112,69; 103,01 mg/dl; dan kadar HDL darah 106,80; 100,50; 106,20 mg/dl. Kadar trigliserida, kolesterol, LDL dan HDL darah tidak berbeda nyata antar perlakuan $(\mathrm{P}>0.05)$. Kesimpulan dari penelitian ini adalah suplementasi baking soda dalam pakan sampai taraf $1 \%$ BK tidak mempengaruhi metabolisme di dalam rumen.
\end{abstract}

Kata kunci : baking soda, trigliserida, kolesterol, lipoprotein.

\section{PENDAHULUAN}

Pencernaan ternak ruminansia sangat bergantung pada aktivitas mikroba dalam rumen. Mikroba rumen bertugas untuk mendegradasi nutrien-nutrien pakan di dalam rumen menjadi komponenkomponen yang lebih sederhana yang dapat dimanfaatkan oleh tubuh. Agar proses tersebut berjalan optimal, mikroba rumen membutuhkan suasana netral, yaitu pada $\mathrm{pH} 5.5$ - 7.0 dan aktivitasnya akan menurun apabila $\mathrm{pH}$ rumen dibawah 5.5. Proses mastikasi di mulut menyebabkan keluarnya saliva yang berguna untuk menyetabilkan $\mathrm{pH}$ dalam rumen (Hoover dan Miller, 1991), namun konsumsi pakan yang mudah dicerna seperti pakan konsentrat, pakan rendah serat, pellet serta pakan hijauan yang telah 
dipotong-potong, menyebabkan proses mastikasi berkurang sehingga pengeluaran saliva kedalam rumen menjadi berkurang, sehingga $\mathrm{pH}$ rumen dapat menurun.

Natrium bikarbonat $\left(\mathrm{NaHCO}_{3}\right)$ atau yang biasa disebut baking soda merupakan hasil reaksi dari basa kuat $(\mathrm{NaOH})$ dan asam lemah $\left(\mathrm{H}_{2} \mathrm{CO}_{3}\right)$ yang dapat berfungsi sebagai buffer (Hashemi et al., 2012). Baking soda berperan dalam membantu saliva dalam menstabilkan $\mathrm{pH}$ rumen dan menyediakan kondisi netral agar mikroba rumen dapat bekerja secara optimal dalam melakukan proses degradasi nutrien di dalam rumen.

Salah satu peran mikroba dalam rumen adalah dalam memetabolisme lemak, mikroba berperan penting dalam proses hidrolisis ester dan biohidrogenasi asam lemak tak jenuh serta fermentasi serat kasar menjadi Volatile Fatty Acid (VFA) yang meliputi asetat, propionat dan butirat. Lemak makanan dalam rumen mengalami proses (1) hidrolisis, yaitu melepaskan asam lemak dari ikatan ester, melepaskan galaktose dari ester galaktosil gliseril dari asam lemak terutama linoleat, (2) fermentasi gliserol dan galaktose yang dilepas dari proses hidrolisis rumen, menjadi VFA, (3) hidrogenasi asam lemak tak jenuh oleh mikroorganisme rumen menjadi asam lemak jenuh (Parakkasi, 1999). Hasil metabolisme lemak dalam rumen ini, kemudian dibawa ke usus halus dan dihidrolisis oleh lipase pankreas menjadi asam-asam lemak bebas dan gliserol. Faktor-faktor yang dapat mempengaruhi proses hidrolisis lemak dalam rumen adalah $\mathrm{pH}$ rumen rendah serta ionophores yang dapat menghambat aktivitas dan pertumbuhan bakteri rumen (Lock et al., 2006).

Lemak merupakan molekul yang tidak larut dalam air (hidrofobik), yang berarti lemak tidak dapat larut dalam plasma darah (Linder, 1992). Lemak harus berikatan dengan protein yang disebut dengan lipoprotein, agar dapat diangkut melalui peredaran darah. Berdasarkan densitasnya lipoprotein dalam darah dibagi menjadi empat, yaitu kilomikron, Very Low Density Lipoprotein (VLDL), Low Density Lipoprotein (LDL) dan High Density Lipoprotein (HDL). Kilomikron dan VLDL bertugas untuk membawa lemak dalam bentuk trigliserida, sedangkan LDL dan HDL bertugas untuk mengangkut kolesterol (Chuzaemi, 2012).

Tujuan dari penelitian ini adalah untuk mengkaji pengaruh suplementasi baking soda dalam pakan terhadap kadar lemak darah, yaitu trigliserida dan kolesterol yang diangkut oleh High Density Lipoprotein (HDL) dan Low Density Lipoprotein (LDL). Manfaat dari penelitian ini adalah dapat menstabilkan metabolisme lemak di dalam rumen, yang tercermin dari profil lemak darah. Hipotesis dari penelitian ini adalah perlakuan baking soda dapat mempengaruhi kadar trigliserida, kolesterol, HDL dan LDL darah.

\section{MATERI DAN METODE}

Penelitian ini dilaksanakan pada tanggal 14 September - 09 November 2016 di Kelompok Tani Ternak (KTT) Susu Makmur, Dusun Banyudono, Desa Gedong, Kecamatan Banyubiru, Kabupaten Semarang, Jawa Tengah.

Materi yang digunakan dalam penelitian ini yaitu 12 ekor sapi perah Peranakan Friesian Holstein (FH) laktasi pada bulan laktasi ke-5 dan ke-6 dengan periode laktasi I. Bobot badan rata-rata $389,17 \pm 27 \mathrm{~kg}$, dengan produksi susu ratarata $13,76 \pm 1,46 \mathrm{~kg} /$ hari. Pakan yang 
digunakan terdiri dari rumput gajah, konsentrat dan pellet, komposisi ransum terdapat pada Tabel 1. Penelitian ini merupakan penelitian eksperimen yang menggunakan rancangan acak lengkap (RAL) dengan tiga perlakuan (T0 = control; $\mathrm{T} 1=$ suplementasi baking soda 0,8\% BK; dan $\mathrm{T} 2=$ Suplementasi baking soda $1,0 \% \mathrm{BK}$ ) dan empat ulangan.

Penelitian dilakukan melalui lima tahap, yaitu tahap persiapan penelitian, tahap adaptasi pakan, tahap perlakuan dan pengambilan data serta tahap analisis data. Tahap persiapan dilakukan selama 30 hari, meliputi persiapan ternak, persiapan ransum serta persiapan suplemen baking soda.Tahap adaptasi dilakukan dengan cara memberikan suplemen baking soda yang dicampur dalam konsentrat sesuai perlakuan selama 7 hari hingga konsumsi pakan stabil. Pemberian pakan dilakukan setiap pagi dan sore setelah pemerahan sesuai dengan ransum yang telah disusun. Sisa pakan ditimbang kemudian menghitung konsumsi pakan sebagai evaluasi kecukupan nutrisi tiap individu ternak. Tahap perlakuan dilakukan selama 21 hari, dengan cara memberikan suplemen baking soda yang telah dicampur dalam konsentrat yang telah diadaptasi sebelumnya. Pengambilan data meliputi pengambilan sampel darah, dengan parameter kadar trigliserida, kolesterol, LDL dan HDL darah. Pengambilan sampel darah dilakukan 3 jam setelah diberi pakan pada pagi hari (Sharma dan Erdman, 1991) pada hari ke-21 penelitian, dengan menggunakan spuit $10 \mathrm{cc}$, kemudian dimasukkan ke dalam tabung yang nonEDTA. Sampel darah disimpan dalam ice box.

Analisis Trigliserida, Kolesterol dan HDL darah dilaksanakan di Rumah Sakit Hewan (RSH) Prof. Soeparwi Universitas Gadjah Mada (UGM) Yogyakarta, menggunakan metode end point dengan alat Ceretium NB-201 SemiAuto Chemistry Analyzer. Kadar LDL darah dihitung menggunakan rumus :

$$
\mathrm{LDL}=\text { Kolesterol }-\left(\mathrm{HDL}+\frac{\mathrm{TG}}{5}\right)
$$

Tabel 1. Kandungan nutrisi pakan dan komposisi ransum

\begin{tabular}{|c|c|c|c|c|c|c|c|}
\hline No & Bahan Pakan & Komposisi & $\mathrm{BK}^{1}$ & $\mathrm{PK}^{1}$ & $\mathrm{LK}^{1}$ & $\mathrm{SK}^{1}$ & $\mathrm{TDN}^{2}$ \\
\hline & & & & $\% \mathrm{BK}$ & -----o & ------ & \\
\hline \multicolumn{7}{|c|}{ Analisis Proksimat } & \\
\hline 2. & Konsentrat & & 83.68 & 12.21 & 4,14 & 1712 & 5663 \\
\hline & Pellet (Cargill) & & 86,44 & 15,84 & 4,22 & 16,06 & 64,12 \\
\hline \multicolumn{8}{|c|}{ Komposisi Ransum } \\
\hline 1. & Rumput Gajah & 58 & 14,73 & 5,30 & 1,66 & 13,53 & 29,07 \\
\hline 2. & Konsentrat & 25 & 20,92 & 3,05 & 1,04 & 4,28 & 14,16 \\
\hline \multirow[t]{2}{*}{3.} & Pellet (Cargill) & 17 & 14,69 & 2,69 & 0,72 & 2,73 & 10,90 \\
\hline & Total & 100 & 50,34 & 11,04 & 3,41 & 20,54 & 54,13 \\
\hline
\end{tabular}

Keterangan :

$\left.{ }^{1}\right)$ Hasil analisis laboratorium Ilmu Nutrisi dan Pakan, Fakultas Peternakan dan Pertanian, Undip.

2) Dihitung dengan rumus Hartadi et al.(1990) 


\section{HASIL DAN PEMBAHASAN}

Hasil analisis sampel darah sapi perah laktasi diperoleh kadar trigliserida, kolesterol, LDL dan HDL darah sapi perah laktasi, disajikan pada Tabel 2.

Tabel 2. Rata-rata kadar trigliserida, kolesterol, LDL dan HDL darah sapi perah laktasi

\begin{tabular}{lrrr}
\hline \multirow{2}{*}{ Parameter } & \multicolumn{3}{c}{ Perlakuan } \\
\cline { 2 - 4 } & \multicolumn{2}{c}{ T0 } & \multicolumn{1}{c}{ T1 } \\
\hline \multirow{2}{*}{ Trigliserida } & $56,11 \pm 6,13$ & $63,56 \pm 7,87$ & $60,14 \pm 14,53$ \\
Kolesterol & $250,16 \pm 21,84$ & $224,30 \pm 31,47$ & $221,18 \pm 24,71$ \\
LDL & $132,09 \pm 12,26$ & $112,69 \pm 19,86$ & $103,01 \pm 21,06$ \\
HDL & $106,80 \pm 10,10$ & $100,50 \pm 15,20$ & $106,20 \pm 6,80$ \\
\hline
\end{tabular}

\section{Kadar Trigliserida Darah}

Kadar trigliserida pada Tabel 2 berada diatas kadar trigliserida darah sapi perah yang dilaporkan oleh Turk et al. (2004) yaitu 7-30 mg/dl, namun masih berada pada kisaran normal menurut Petkova et al. (2008) bahwa kadar trigliserida darah pada sapi perah dikatakan normal apabila kurang dari 150 $\mathrm{mg} / \mathrm{dl}$ dan dikatakan sangat tinggi apabila melebihi $500 \mathrm{mg} / \mathrm{dl}$. Kadar trigliserida sangat dipengaruhi oleh kandungan lemak dan karbohidrat pakan yang dikonsumsi. Soehardi (2004) menyatakan bahwa trigliserida berasal dari lemak pakan (asam lemak jenuh dan tidak jenuh) dan berasal dari pakan yang mengandung karbohidrat (sederhana dan kompleks). Trigliserida digunakan sebagai sumber energi dan kelebihannya akan disimpan di hati sebagai cadangan energi. Menurut Champe et al. (2005) pembentukan trigliserida diregulasi oleh hormon insulin dengan proses yang dikenal sebagai lipogenesis, apabila kadar trigliserida yang masuk dalam tubuh lebih tinggi daripada kebutuhan energi maka akan disimpan sebagai depot lemak (cadangan energi).

Analisis ragam menunjukkan bahwa suplementasi baking soda dalam pakan tidak berpengaruh nyata $(\mathrm{P}>0,05)$ terhadap kadar trigliserida darah. Hasil ini menunjukkan bahwa suplementasi baking soda dalam pakan sampai taraf $1 \%$ tidak mengakibatkan perubahan metabolisme lemak di dalam rumen. Hal ini mungkin terjadi karena pakan yang dikonsumsi mengandung sedikit konsentrat (Tabel 1.), sehingga penurunan $\mathrm{pH}$ akibat pakan konsentrat tidak signifikan atau dengan kata lain $\mathrm{pH}$ di dalam rumen masih dalam kondisi stabil. Aswandi et al. (2012) berpendapat bahwa jenis pakan yang mengandung lebih banyak pati atau karbohidrat yang mudah larut maka $\mathrm{pH}$ cenderung rendah. Menurut Staples dan Lough (1989) baking soda efektif pada ternak dengan pakan 50-60\% konsentrat.

\section{Kadar Kolesterol Darah}

Berdasarkan data pada Tabel 2 kadar kolesterol berada pada rata-rata atas hasil penelitian yang dilakukan Turk et al. (2004) yaitu 130-252 mg/dl. Kadar kolesterol dipengaruhi oleh kandungan lemak pakan. Serjsen et al. (2008) menyatakan bahwa lemak pakan khususnya asam lemak jenuh seperti laurat, miristat, dan palmitat dapat meningkatkan kadar total kolesterol dalam darah. Kadar kolesterol darah sangat berhubungan 
dengan dengan kadar HDL dan LDL. Menurut Hasanudin et al. (2013) LDL berperan dalam menyediakan kolesterol dalam jaringan tubuh karena merupakan karier utama untuk kolesterol dari hati ke jaringan tubuh, sehingga kadar LDL dalam darah dipengaruhi oleh konsentrasi kolesterol, HDL berperan mengembalikan kolesterol berlebihan yang dibawa oleh LDL ke hati.

Berdasarkan analisis ragam dapat diketahui bahwa suplementasi baking soda dalam pakan tidak berpengaruh nyata $(\mathrm{P}>0,05)$ terhadap kadar kolesterol darah sapi perah laktasi. Hal ini disebabkan karena baking soda tidak secara langsung terlibat dalam sintesis kolesterol. Baking soda berperan dalam organ pencernaan khususnya rumen dalam menyediakan suasana netral agar mikroba dapat bekerja optimal dalam proses pencernaan pakan menghasilkan VFA terutama propionat yang kemudian dibawa ke hati dan mengalami proses glukoneogenesis menjadi glukosa sebagai sumber energi, glukosa yang tidak dipakai sebagai sumber energi disimpan di dalam hati sebagai cadangan energi. Glukosa tersebut dapat diubah menjadi asetil-KoA yang merupakan prekursor pembentukan kolesterol yang dibawa oleh LDL. Hal ini sesuai dengan pendapat Rettersol et al. (1998) bahwa biosintesis kolesterol terutama terjadi di dalam jaringan hati, $33 \%$ berasal dari makanan dan $67 \%$ disintesis dalam tubuh. Marks et al. (2000) berpendapat bahwa prekursor pembentukan kolesterol adalah asetil KoA yang diperoleh dari sitoplasma. Asetil KoA dihasilkan dari glukosa dan asam lemak dalam mitokondria serta katabolisme asam amino.

\section{Kadar LDL Darah}

Hasil pengukuran kadar LDL pada Tabel 2 sesuai dengan pengukuran yang dilakukan oleh Turk et al. (2004) yaitu 44$141 \mathrm{mg} / \mathrm{dl}$. LDL berperan penting dalam pendistribusian kolestrol ke jaringan tubuh. Menurut Weatherby dan Ferguson (2002) LDL berperan dalam menyediakan kolesterol dalam jaringan tubuh karena merupakan carrier utama untuk kolesterol dari hati ke dalam jaringan tubuh. LDL membawa kolesterol dari hati menuju jaringan dan sel-sel yang mengandung reseptor LDL guna dimanfaatkan sel tersebut serta untuk sintesis membran dan hormon steroid.

Berdasarkan analisis ragam dapat diketahui bahwa suplementasi baking soda dalam pakan tidak berpengaruh nyata $(\mathrm{P}>0,05)$ terhadap kadar LDL darah sapi perah laktasi. Hal ini dikarenakan suplementasi baking soda yang belum optimal mambantu metabolisme lemak pakan yang hasilnya adalah asam lemak dan gliserol serta sedikit kolesterol pakan. Menurut Hashemi et al. (2012) baking soda telah dikenal sebagai buffer alami yang dapat menstabilkan $\mathrm{pH}$ rumen sehingga dapat mengoptimalkan kerja mikroba rumen dalam proses hidrogenasi lemak pakan. Hasil metabolisme lemak pakan yang dikonsumsi sebagian besar berupa asam lemak dan gliserol yang akan masuk ke dalam darah berupa trigliserida dan sedikit kolesterol yang dibawa oleh kilomikron ke seluruh jaringan tubuh. Sisasisa kilomikron inilah yang nantinya dibawa ke hati dan ditangkap oleh reseptor LDL bersamaan dengan IDL yang akan bertransformasi menjadi LDL. Bouchart (1993) menyatakan bahwa LDL merupakan produk akhir degradasi intravaskular VLDL (yang bertugas membawa trigliserida dari hati ke jaringan) melalui IDL. 


\section{Kadar HDL darah}

Berdasarkan Tabel 2 kadar HDL darah sapi perah sesuai dengan pengukuran kadar HDL yang dilakukan oleh Petkova et al. (2008) yaitu 93,44-111,58 mg/dl. HDL dalam darah dapat berpengaruh baik terhadap ternak karena HDL dikenal sebagai kolesterol baik. Bouchart (1993) menyatakan bahwa HDL berperan penting dalam reverse cholesterol transport system atau sistem transportasi kolesterol terbalik yang mengembalikan kelebihan kolesterol dari sel-sel perifer ke hati untuk ekskresi empedu dan resintesis partikel VLDL baru.

Berdasarkan analisis ragam dapat diketahui bahwa suplementasi baking soda dalam pakan tidak berpengaruh nyata ( $>0$,05) terhadap kadar HDL darah sapi perah laktasi. Hal ini mungkin disebabkan karena HDL disintesis di hati dan diregulasi oleh kandungan kolesterol darah, sedangkan baking soda lebih banyak berperan di rumen, untuk membantu proses metabolisme lemak pakan menjadi asamasam lemak yang dibawa oleh darah dalam bentuk kilomikron. Menurut Bouchart (1993) HDL disintesis dan disekresi oleh hati sebagai partikel discoidal yang menjadi bulat selama pembentukan ester kolesterol dengan bantuan enzim LCAT (lecithin: cholesterol acyltransferase). Hasanudin et al. (2013) menyatakan bahwa HDL merupakan lipoprotein yang menjaga keseimbangan kolesterol agar tidak menumpuk di dalam sel, keseimbangan dikelola oleh pengangkatan sterol dari membran pada tingkat yang sama dengan jumlah kolesterol yang disintesis menuju hati.

\section{KESIMPULAN}

Penelitian suplementasi baking soda sampai taraf $1 \%$ BK belum mampu meningkatkan metabolisme lemak dalam rumen, yang tercermin pada hasil penelitian yang menunjukan tidak ada perbedaan baik pada kadar trigliserida, kolesterol, LDL maupun HDL darah sapi perah laktasi. Penelitian lanjutan diperlukan untuk mengetahui dosis baking soda yang lebih tinggi dengan pakan tinggi konsentrat.

\section{DAFTAR PUSTAKA}

Aswandi, C.I. Sutrisno, M.Arifin dan A. Joelal. 2012. Efek complete feed bonggol berbagai varietas tanaman pisang terhadap $\mathrm{pH}, \mathrm{NH}_{3}$ dan VFA pada kambing kacang. JITP 2(2): 99109.

Bouchart, D. 1993. Lipid Absorption and Transport in Ruminants. J Dairy Sci 76:3864-3881.

Champe, P.C., R.A. Harvey and D.P. Ferrier. 2005. Biochemistry, $3^{\text {nd }}$ Revised Edition. Lippincott Williams and Walkins, Philadelpia.

Chuzaemi, S. 2012. Fisiologi Nutrisi Ruminansia. UB Press, Malang.

Hasanudin, S., V.D. Yunianto dan Tristiarti. 2013. Profil lemak darah pada ayam broiler yang diberi pakan step down protein dengan penambahan air perasan jeruk nipis sebagai acidifier. JITP. 3(1): 11-17.

Hashemi, M., F. Zamani, M. Vatankhah and S.H. Zadeh. 2012. Effect of Sodium Bicarbonate and Magnesium Oxide on performance and carcass characteristics of lori-bakhtiari fattening ram lambs. Global Veterinaria. $\quad 8(1): \quad 89-92$. 
Hoover, W.H. and T.K. Miller. 1992. Rumen Digestive Physiologi and Microbial Ecology. Veterinary Clinics of North America; Food Animal Practice.7(2): 311-325.

Linder, M. C. 1992. Biokimia Nutrisi dan Metabolisme. Universitas Indonesia Press, Jakarta. (Diterjemahkan oleh: A. Parakkasi dan A.Y. Amwila).

Lock, A.L., K.J. Harvatine, J.K. Drackley and D.E. Bauman. 2006. Concepts in fat and fatty acid digestion in ruminants. Proc. Intermountain Nutr. Conf. pp. 85-100.

Marks, D. B., A. D. Marks, dan C. M. Smith. 2000. Biokimia Kedokteran Dasar Sebuah Pendekatan Klinis. EGC, Jakarta. (Diterjemahkan oleh B.U. Pendit).

Parakkasi, A. 1999. Ilmu Nutrisi dan Makanan Ternak Ruminansia. Universitas Indonesia Press, Jakarta.

Petkova, M., I. Kitanov and D. Girginov. 2008. Blood lipids profile in lactating cows fed with supplement ovocap. Biotechnology ini Animal Husbandry. 24(3-4): 19-28.

Rettersol, K. T., B. Ugen, B. Woldseth and B.O. Christopherson. 1998. A comparative study of the metabolism of n-9, n-6 and n-3 fatty acids in testicular cells from immature rat. Biochim. Biophys. Acta. 1392:59-72.
Sejrsen, K., T. Hvelplund and M. O. Nielsen. 2008. Ruminant Physiology. Weningen Academic Publishers, Netherland.

Sharma, B. and R. A. Erdman. 1991. Effect of dietary rumen-protected choline in lactating dairy cows. J. Dairy Sci. 74(5):1641-1647.

Soehardi, S. 2004. Memelihara Kesehatan Jasmani melalui Makanan. Penerbit Institut Teknologi Bandung. Bandung.

Staples, C.R. and D.S. Lough. 1989. Efficacy of supplemental dietary neutralizing agents for lactating dairy cows: A review. Animal Feed Science and Technology. 23: 277303.

Turk, R., D. Juretic, D. Geres, N. Turk, B. Rekic, V. Simeon-Rudolf and A. Svetina. 2004. Serum paraoxonase activity and lipid parameters in the early post partum period of dairy cows. Research ini Veterinary Science.76: 57-61.

Weatherby, D. and S. Ferguson. 2002. Blood Chemistry and CBC AnalysisClinical Laboratory Testing from a Functional Perspective. Bear Mountain Publishing, United State of America. 